Haya: The Saudi Journal of Life Sciences

Abbreviated Key Title: Haya Saudi J Life Sci ISSN 2415-623X (Print) |ISSN 2415-6221 (Online) Scholars Middle East Publishers, Dubai, United Arab Emirates Journal homepage: http://scholarsmepub.com/haya/

Original Research Article

\title{
Assessing Production and Economics of Mono Sex Male Tilapia (Oreochromis niloticus) in Small Seasonal Ponds
}

\author{
Md. Anwar Hossain Mondal ${ }^{1 *}$, Md. Mehedi Hasan Sikdar ${ }^{2}$, Susmita Saha ${ }^{3}$, Jannatun Nayeem Neela ${ }^{4}$ \\ ${ }^{1}$ Assistant Professor, Department of Aquaculture, Faculty of Fisheries, Patuakhali Science and Technology University, Dumki - Patuakhali-8602, \\ Bangladesh \\ ${ }^{2}$ Professor, Department of Statistics, Faculty of Agriculture, Patuakhali Science and Technology University, Dumki - Patuakhali-8602, Bangladesh \\ ${ }^{3,4}$ M.S. in Aquaculture, Faculty of Fisheries, Patuakhali Science and Technology University, Dumki - Patuakhali - 8602, Bangladesh
}

DOI: $10.36348 /$ sj1s.2020.v05i06.004

| Received: 14.05.2020 | Accepted: 27.05.2020 | Published: 25.06.2020

*Corresponding author: Dr. Md. Anwar Hossain Mondal

\section{Abstract}

The study was conducted to assess the production and economics of mono sex male tilapia (Oreochromis niloticus) reared in nine seasonal small ponds at Patuakhali Science and Technology University research farm for a period of three months during March to May 2019.The experiment was designed in three treatments (T) each with three replications. The ponds were drained, limed and fertilized with organic and inorganic fertilizers during preparation. The stocking density was $37050 \mathrm{fish} / \mathrm{ha}$ in all three treatments. After stocking the fish ponds were fertilized weekly with cowdung, urea and TSP. Supplementary feed was not given in $\mathrm{T}_{1}$, but rice bran and mustard oilcake were given in $\mathrm{T}_{2}$ and commercial pellet feed in $\mathrm{T}_{3}$. Some water quality parameters were monitored at regular intervals and they were found within acceptable range for pond aquaculture. The survival rates were high $(>96 \%)$ in all treatments. Significantly highest production $(5494.10 \mathrm{~kg} / \mathrm{ha}$ in three months) was found in $\mathrm{T}_{3}$ followed by $\mathrm{T}_{2}(2392.23 \mathrm{~kg} / \mathrm{ha} / 3$ months $)$ and $\mathrm{T}_{1}(1048.93 \mathrm{~kg} / \mathrm{ha} / 3 \mathrm{months})$. Similarly, significantly highest net return (Tk. 206274.64/ha with benefit cost ratio of 2.01) was found in $\mathrm{T}_{3}$ followed by $\mathrm{T}_{2}$ (Tk.33100.47/ha with benefit cost ratio of 1.24) and $\mathrm{T}_{1}$ (Tk. 8254.74/ha with benefit cost ratio of 1.11).

Keywords: Monosex male tilapia, Seasonal, Pond, Production, Bangladesh.

Copyright @ 2020: This is an open-access article distributed under the terms of the Creative Commons Attribution license which permits unrestricted use, distribution, and reproduction in any medium for non-commercial use (NonCommercial, or CC-BY-NC) provided the original author and source are credited.

\section{INTRODUCTION}

Genetically Improved Farmed Tilapia (GIFT) strain, a synthetic strain of Oreochromis niloticus that was developed through selection of several generations from a base involving eight different strains of Nile tilapia (O. niloticus), was introduced in Bangladesh in July 1994 from Philippines [1].

The GIFT strain was reported to show an average $60 \%$ faster growth and $50 \%$ better survival at harvest than most commonly farmed strain [2, 3]. Tilapia has comparatively good market price, become marketable size in 3-5 months and requires low input cost. It is also preferred both by farmers and consumers due to its fast growth and tasty flesh. Tilapia can grow in a wide range of environmental condition and has good resistance to poor water quality and disease [4]. In Bangladesh, culture of tilapias has been promoted in small, seasonal ditches for poor marginal farmers [5, 6]. Fish farmers in rural areas can effectively utilize these seasonal water bodies for fish culture either for their subsistence or economical benefits. Tilapia, the most important aqua cultured species has been already named as the "food fish of the 21st century" [7] and has poultry broiler like growth with a short culture period. Mono-sex population of male tilapia was produced by treating fry with a synthetic male hormone $17 \alpha$ methyl testosterone at a treatment regime of $10 \mathrm{mg} / \mathrm{kg}$ food for 30 days. The healthy cultivation of tilapia depends on nutritional status and rearing environmental conditions [8]. Supplementary feed is one of the key inputs in fish culture to get high production. Feed cost generally constitutes the highest single operating cost in semi intensive farming operation [9]. Increased natural food produced in fish ponds through fertilization reduces the use of supplementary feeds that ultimately reduces the feed costs. In Bangladesh some relatively cheap indigenous agricultural by-products, such as, rice bran, wheat bran, mustard oilcake are being used for aquaculture. For proper growth of fish, animal protein supplement, growth promoting vitamins and micronutrients are essential. In recent years, pelleted commercial fish feeds have been marketed by different industries. These feeds are mainly used by medium to large farmers in commercial fish farms. For marginal resource poor farmers it is important to improve the 
traditional fish culture system. Mono sex male tilapia is omnivorous and its production can be increased through partial feed supplementation. The present study was conducted to learn about the production and profitability of monosex male tilapia culture under different feeding strategies in seasonal small ponds.

\section{MATERIALS AND METHODS \\ Experimental site and pond facilities}

The experiment was carried out for a period of 92 days from 1 March to 31 May, 2019, in nine experimental ponds situated in the Field research farm, Faculty of Fisheries, Patuakhali Science and Technology University (PSTU), Dumki, Patuakhali. The ponds were equal in size $\left(120 \mathrm{~m}^{2}\right)$ and similar in shape, depth and basin configuration.

\section{Pond Preparation}

The ponds were drained out completely and aquatic weeds were removed manually. Liming was done in all ponds at the rate of $1 \mathrm{~kg} / \mathrm{decimal}$. Three days after liming the ponds were manured with cowdung at the rate of $4 \mathrm{~kg} / \mathrm{decimal}$. One week after liming the ponds were filled with water and fertilized with urea and TSP at the rate of $100 \mathrm{~g} /$ decimal. TSP was soaked overnight, then urea and TSP were dissolved together and spreaded manually on pond water surface in the morning at $10 \mathrm{am}$ with sufficient sunlight.

\section{Collection of experimental fish and stocking}

All the mono sex male tilapia fingerlings with mean initial weight of $4.55 \pm 0.03 \mathrm{~g}$ were collected from a local fish vendor and were stocked at a rate of $150 \mathrm{fish} /$ decimal (37500 fish/ha).

\section{Experimental design and feeding}

The experiment was carried out with three treatments each with three replications. Fertilization was done weekly in the ponds of all treatments at the same rate (cowdung, $3 \mathrm{~kg} /$ decimal; urea, $40 \mathrm{~g} / \mathrm{decimal}$ and TSP, $40 \mathrm{~g} /$ decimal). Supplemental feeds were given in treatment-2 $\left(\mathrm{T}_{2}\right)$ (rice bran: mustard oilcake; $\left.1: 1\right)$ and in treatment-3 $\left(\mathrm{T}_{3}\right)$ (commercial pellet feed containing $32 \%$ protein). The feed was applied at the rate of $5 \%$ of the body weight of fishes at the beginning of the experiment, and then it was reduced to $4 \%$ after one month and 3\% after two months. Feed was applied twice a day, half in the morning $(9.00 \mathrm{am})$ and the rest in the afternoon $(4.00 \mathrm{pm})$. The supplementary feeds, such as rice bran and mustard oilcake were given to the fish in dough form. For this purpose, mustard oilcake was soaked overnight, mixed with rice bran and small balls were made. The feeds were gently thrown over the ponds water on a particular site of the ponds regularly. Twenty percent of the total fish were sampled fortnightly by a seine net to monitor the fish growth and to adjust feeding rates. The weight of fish during sampling was measured by using a portable digital balance.

\section{Water Quality Parameters}

The water quality parameters such as temperature, dissolved oxygen (DO) and $\mathrm{pH}$ were recorded fortnightly. The temperature and dissolved oxygen of the ponds were determined by a DO meter (YSI, model 58, USA). Secchi disc visibility was measured using a Secchi disc at the time of water sampling. The water $\mathrm{pH}$ was recorded by a $\mathrm{pH}$ meter (Jenway, model 3020, UK). Integrated water sample of entire column was taken at fortnightly interval for analysis of chlorophyll- $a$ [10].

\section{Statistical Analysis}

For data analysis a one-way ANOVA and DMRT were applied following Gomez and Gomez [11]. Computer analysis of the data was done by using the software SPSS (Statistical Package for Social Science) version 20.0 Significance was assigned at $0.05 \%$ level.

\section{Economic Analysis}

An economic analysis was conducted to estimate the net profit from different treatments. The analysis was based on local market prices for harvested fish and all other items. The costs of fingerlings, fertilizer and supplemental feeds are shown in Table-3. The cost of leasing ponds was not included in the total cost. An additional $7.5 \%$ on total cost was included as operational cost [12]. The net return was measured by deducting the gross cost from the gross return per decimal. The benefit cost ratio was also measured as a ratio of net benefit to gross cost.

\section{RESULTS \\ Water Quality Parameters}

The water quality parameters measured during the experimental period is furnished in Table- 1 and found that the water quality parameters were within the expectable range among the treatments for pond aquaculture and only significant differences were found among the treatments regarding transparency and Chlorophyll- $a$ (Table-1).

Table-1: Mean ( \pm SD) values and ranges (in parentheses) of water quality parameters of experimental ponds under three treatments during the study period

\begin{tabular}{|l|l|l|}
\hline Parameters & Treatments & Level of \\
\hline
\end{tabular}




\begin{tabular}{|l|l|l|l|l|}
\hline & $\mathbf{T}_{\mathbf{1}}$ & $\mathbf{T}_{\mathbf{2}}$ & \multicolumn{1}{c|}{$\mathbf{T}_{\mathbf{3}}$} & Significance \\
\hline & & & & \\
\hline Temperature $\left({ }^{\circ} \mathrm{C}\right)$ & $30.96 \pm 0.53$ & $31.08 \pm 0.47$ & $31.03 \pm 0.55$ & NS \\
\hline Transparency $(\mathrm{cm})$ & $24.62 \pm 0.84 \mathrm{~b}$ & $30.29 \pm 0.81 \mathrm{~b}$ & $37.28 \pm 1.28 \mathrm{a}$ & $*$ \\
\hline Dissolved oxygen $(\mathrm{mg} / \mathrm{l})$ & $5.37 \pm 0.15$ & $5.16 \pm 0.08$ & $5.46 \pm 0.17$ & NS \\
\hline $\mathrm{pH}$ & $7.74 \pm 0.18$ & $7.64 \pm 0.13$ & $7.62 \pm 0.16$ & NS \\
\hline Chlorophyll- $a(\mu \mathrm{g} / \mathrm{l})$ & $129.67 \pm 15.76 \mathrm{~b}$ & $156.57 \pm 39.72 \mathrm{~b}$ & $248.95 \pm 55.33 \mathrm{a}$ & $*$ \\
\hline
\end{tabular}

Mean values with different superscripts in the same row are significantly different $(\mathrm{p}<0.05)$; NS-Non significant; * Significant

\section{Growth and Production Performances}

The growth performance of mono sex male tilapia in terms of initial weight, final weight, weight gain, specific growth rate, feed conversion ratio, survival rate and total production is shown in Table-2. Mean weight gain of mono sex male tilapia ranged between 23.58 and $148.50 \mathrm{~g}$ and there was a significant variation $(\mathrm{p}<0.05)$ among the treatments (Table 2$)$. The mean weight gain was significantly higher $(\mathrm{p}<0.05)$ in $\mathrm{T}_{3}(146.69 \mathrm{~g})$ than in $\mathrm{T}_{1}(24.72 \mathrm{~g})$ and $\mathrm{T}_{2}(60.19 \mathrm{~g})$. Significantly highest $(\mathrm{p}<0.05)$ SGR value $(1.98)$ was recorded in $\mathrm{T}_{3}$ and the lowest (1.21) in $\mathrm{T}_{1}$ (Table-2).

Table-2: Growth and production of mono sex male tilapia observed in different treatments during the experimental period

\begin{tabular}{|l|l|l|l|}
\hline Parameters & Treatments & $\mathbf{T}_{\mathbf{3}}$ \\
\hline & $\mathbf{T}_{\mathbf{1}}$ & $\mathbf{T}_{\mathbf{2}}$ & $4.55 \pm 0.03$ \\
\hline Initial weight $(\mathrm{g})$ & $4.55 \pm 0.03$ & $4.55 \pm 0.03$ & $151.24 \pm 1.79 \mathrm{a}$ \\
\hline Final weight $(\mathrm{g})$ & $29.27 \pm 1.16 \mathrm{c}$ & $64.74 \pm 1.18 \mathrm{~b}$ & $146.69 \pm 1.81 \mathrm{a}$ \\
\hline Weight gain $(\mathrm{g})$ & $24.72 \pm 1.14 \mathrm{c}$ & $60.19 \pm 1.16 \mathrm{~b}$ & $322.95 \pm 24.04 \mathrm{a}$ \\
\hline$\%$ Weight gain $(\mathrm{g})$ & $643.29 \pm 19.54 \mathrm{c}$ & $1422.85 \pm 15.65 \mathrm{~b}$ & $3223.02 \mathrm{a}$ \\
\hline SGR $\%$ day) & $1.21 \pm 0.02 \mathrm{c}$ & $1.47 \pm 0.01 \mathrm{~b}$ & $1.98 \pm 0.02 \mathrm{a}$ \\
\hline FCR & - & $1.71 \pm 0.01$ & $1.36 \pm 0.03$ \\
\hline Survival rate (\%) & $96.76 \pm 1.15$ & $97.10 \pm 1.25$ & $98.05 \pm 0.57$ \\
\hline Production (kg/pond/3 months) & $12.74 \pm 1.15 \mathrm{c}$ & $28.29 \pm 1.14 \mathrm{~b}$ & $66.73 \pm 1.17 \mathrm{a}$ \\
\hline Total production (kg/ha/3 months) & $1048.93 \pm 11.55 \mathrm{c}$ & $2392.23 \pm 9.52 \mathrm{~b}$ & $5494.10 \pm 11.55 \mathrm{a}$ \\
\hline
\end{tabular}

The FCR was 1.71 and 1.36 in $\mathrm{T}_{2}$ and $\mathrm{T}_{3}$ respectively. The survival rate ranged between 96.76 to $98.05 \%$ and there was no significant difference ( $p>0.05)$ among the treatments. The production of mono sex male tilapia in terms of $\mathrm{kg} / \mathrm{ha} / 3$ months was highest $(5494.10 \mathrm{~kg})$ in $\mathrm{T}_{3}$, followed by $\mathrm{T}_{2}(2392.23 \mathrm{~kg})$ and $\mathrm{T}_{1}(1048.93 \mathrm{~kg})$ and they were significantly $(\mathrm{p}<0.05)$ different (Table-2). A simple economic analysis showed that $T_{3}$ generated the highest benefit or net return of Tk. 2,06,274.64/ha/3 /ha/3months and Benefit Cost Ratio (BCR) of 2.01 followed by Tk. $33100.4 / \mathrm{ha} / 3$ months and $\mathrm{BCR}$ value of 1.24 in $\mathrm{T}_{2}$ and Tk. 8254.74/ha/3 months and BCR value of 1.11 in $\mathrm{T}_{1}$ (Table-3).

Table-3: Economic analysis of mono sex male tilapia $(O$. niloticus) production in ponds reared for 3 months

\begin{tabular}{|l|l|l|l|}
\hline \multicolumn{1}{|c|}{ Components } & Treatments & T2 \\
\hline Expenditure (Tk/pond) & & & \\
\hline Fingerlings cost & 450 & 450 & 450 \\
\hline Feed cost & - & 793.00 & $1,620.00$ \\
\hline Lime cost & 120.00 & 120.00 & 120.00 \\
\hline Cow dung & 110.0 & 85.00 & 55.00 \\
\hline Urea & 50.00 & 50.00 & 35.00 \\
\hline TSP & 65.00 & 55.00 & 45.00 \\
\hline Operational cost & $60.00 \pm 1.20$ & $116.00 \pm 1.14$ & $174.38 \pm 0.58$ \\
\hline Total expenditures (Tk/pond) & $855.24 \pm 1.13 \mathrm{c}$ & $1,719.72 \pm 1.16 \mathrm{~b}$ & $2,499.39 \pm 2.79 \mathrm{a}$ \\
\hline Income & \multicolumn{5}{|l|}{} \\
\hline Gross return (Tk/pond) & $955.50 \pm 5.75 \mathrm{c}$ & $2121.75 \pm 1.17 \mathrm{~b}$ & $5004.75 \pm 1.15 \mathrm{a}$ \\
\hline Net return (Tk/pond) & $100.26 \pm 0.58 \mathrm{c}$ & $402.03 \pm 1.15 \mathrm{~b}$ & $2505.36 \pm 1.15 \mathrm{a}$ \\
\hline Net return (Tk/ha) & $8254.74 \pm 0.58 \mathrm{c}$ & $33100.47 \pm 2.31 \mathrm{~b}$ & $206274.64 \pm 57.74 \mathrm{a}$ \\
\hline BCR (Benefit Cost Ratio) & $1.11 \pm 0.01$ & $1.24 \pm 0.03$ & $2.01 \pm 0.05$ \\
\hline
\end{tabular}

Mean values with different superscripts in the same row are significantly different $(p<0.05)$ Sale price of mono sex male tilapia $=$ Taka $75.00 / \mathrm{kg}$. Leasing cost for pond is not included.

Operational cost is considered as $7.5 \%$ of total cost (ADCP, 1983).

\section{DISCUSSION}

The rearing experiment of mono sex male tilapia was conducted during March to May when the environmental temperature was very suitable for aquaculture. The surface water temperature of the ponds ranged from 30.96 to $31.58^{\circ} \mathrm{C}$. Hossain et al., 
[13] reported that conditions are highly suited for raising tilapia between March and May when temperature varies from $25^{\circ} \mathrm{C}$ to $35^{\circ} \mathrm{C}$.

DoF [14] reported that the range of suitable dissolved oxygen for fish culture would be $5-8 \mathrm{mg} / \mathrm{l}$. In the present study dissolved oxygen concentration ranged from 5.22 to $5.63 \mathrm{mg} / \mathrm{l}$. DO content in the present study was slightly lower. This might be due to the measurement of DO at morning (10.00 am). However, this low DO level might have not any negative effect since tilapia has high tolerance to environmental fluctuation. The $\mathrm{pH}$ of water in the experimental ponds ranged between $7.74 \pm 0.18$ and $7.62 \pm 0.16$ which is considered suitable as suggested by some other authors $[15,14]$.

Transparency ranged from 23.78 to $38.56 \mathrm{~cm}$ and the mean values were $24.62,30.29$ and $37.28 \mathrm{~cm}$ in $\mathrm{T}_{1}, \quad \mathrm{~T}_{2}$ and $\mathrm{T}_{3}$ respectively. The variation in transparency was due to plankton production and rain induced turbidity. Similar transparency values were recorded by Latif et al., [16]; Wahab et al., [17].

The mean chlorophyll- $a$ values recorded in the present study were $129.67,156.57$ and $248.95 \mu \mathrm{g} / \mathrm{l}$ in $\mathrm{T}_{1}, \mathrm{~T}_{2}$ and $\mathrm{T}_{3}$ respectively. The highest chlorophyll- $a$ values was found in $T_{3}$ that might be due to higher concentration of phytoplankton in the ponds. The lower mean value was observed in $T_{1}$ that might be due to the grazing pressure of fish in natural food because supplemental feed was not given in that treatment.

In this study, mean weight gain of Mono sex male tilapia were $24.72 \mathrm{~g}, 60.19 \mathrm{~g}$ and $146.69 \mathrm{~g}$ and percent weight gain were 643.29, 1422.85 and $3223.95 \%$ in $\mathrm{T}_{1}, \mathrm{~T}_{2}, \mathrm{~T}_{3}$ respectively. From the study, it is found that mean weight gain and percent weight gain were significantly higher in $\mathrm{T}_{3}$ than $\mathrm{T}_{2}$ and $\mathrm{T}_{1}$. This is due to utilization of natural foods in the ponds as well as the use of supplementary pellet feed. Lower value of mean weight gain and percent weight gain in $\mathrm{T}_{1}$ was due to no use of any supplementary feed. Hussain et al., [1] reported a weight gain of about $128 \mathrm{~g}$ for GIFT strain in on-farm ponds for a culture period of 6 months fed rice bran at 5-6\% of their body weight. Considering the 3 months culture period in the present study compared to 6 months period by Hussain et al., [1], mono sex male tilapia in the present study performed better. This difference in the growth might be related to feed $\&$ fertilizer supplied in the ponds and the time/ season of the experiment. Hussain et al., [1] conducted the experiment from January to May which covered part of the winter season when growth of fish is generally slow.

In this study, Specific Growth Rate (SGR) value of mono sex male tilapia was $1.21,1.47$ and $1.98 \%$ in $\mathrm{T}_{1}, \mathrm{~T}_{2}$ and $\mathrm{T}_{3}$ respectively. The highest SGR value in $\mathrm{T}_{3}$ was due to high protein and energy content of the diet compared to other treatments. Green [18] obtained a higher SGR value of 2.03 with tilapia in Honduras using feed and fertilizer. Hossain et al. (2004) also observed SGR values of GIFT tilapia ranged from 2.04 to 2.30 fed on formulated diet. The lower SGR values of mono sex male tilapia ( $O$. niloticus) in the study might be due to the protein and energy content of the diet and natural productivity of the ponds.

The Food Conversion Ration (FCR) values found in $T_{2}$ and $T_{3}$ were 1.71 and 1.36 respectively. Hossain [19] found FCR value of GIFT tilapia fed rice bran and commercial tilapia feed as 2.07 and 1.84. The variation in FCR values might be due to difference in quality of food given. The survival rate of the fishes were high and ranged between 96.76 and $98.05 \%$. Similar higher survival of mono sex male tilapia was recorded by Hossain et al., [20] and DoF [14]. The higher survival of fish in the study might be related to the relatively larger size of fingerlings $(4.55 \mathrm{~g})$ stocked and care during the rearing period.

The total production of fishes was 1048.93, 2392.23 and $5494.10 \mathrm{~kg} / \mathrm{ha} / 3$ months in $\mathrm{T}_{1}, \mathrm{~T}_{2}$ and $\mathrm{T}_{3}$ respectively, and varied significantly among the treatments. The highest production found in $\mathrm{T}_{3}$ might be due to high protein quality supplementary-pelleted feed and large quantity of natural food available in the pond during the study period, and this production is more or less similar to the findings of Hossain et al., [20] and Hossain [19]. Boyd [21] reported that feeding plus fertilization can increase fish production over that possible with fertilization alone. Gupta et al., [22] reported that tilapia production of $3554.76 \mathrm{~kg} / \mathrm{ha}$ in treatment receiving supplementary feed than 1510.71 $\mathrm{kg} / \mathrm{ha}$ in fertilized ponds for 6 months. Green et al., [23] reported yields ranged from 1274 to $2929 \mathrm{~kg} / \mathrm{ha} / 145$ days. The difference in total production found by different authors might be due to the variation in productivity of the ponds, variation of rearing season and cultural periods along with other factors.

The net return and benefit cost ratio was higher in $\mathrm{T}_{3}$ where pellet feed was used. Possibly the feed (rice bran + oil cake) given in $\mathrm{T}_{2}$ could not fulfill the nutritional requirement of the fishes in that treatment as a result the fish production, net income and benefit cost ratio was lower. As no food was given in $T_{1}$ so the production was very low in that treatment.

The research findings revealed that pellet feed having nutritional requirements in good form than other two treatments resulting high production and net income.

\section{REFERENCES}

1. Hussain, M. G., Kohinoor, A. H. M., Islam, M. S., Mahata, S. C., Ali, M. Z., Tanu, M. B., Hossain, 
M. A., \& Mazid, M. A. (2000). Genetic evaluation of GIFT and existing strains of Nile tilapia, Oreochromis niloticus L., under on-station and onfarm conditions in Bangladesh. Asian Fish Sci, 13: 117-126.

2. Eknath, A. E. (1992). Growth capacity of Tilapia in intensive culture. Bamidgheh, 32(3): 57-65.

3. Sultana, R., Kohinoor, A. H. M., Islam, M. S., Mazid, M. A., \& Hussain, M. G. (1997). Comparative studies on growth of fry of GIFT and existing strain of Nile tilapia (Oreochromis niloticus). Bangladesh J Fish Res, 1(1): 25-30.

4. Balarin, J. D., \& Haller, R. D. (1982). The intensive culture of tilapia in tanks, raceways and cages. In: Recent Advances in Aquaculture, Muir, J. F., \& Roberts, J. J. (eds.). Westview Press, Boulder, Colorado, 265-365.

5. Hussain, M. G., Rahman, M. A., Akhteruzzaman, M., \& Kohinoor, A. H. M. (1989). Study on the production of Oreochromis niloticus under semi intensive system in Bangladesh. Bangladesh $J$ Fish, 12(1): 59-65.

6. Gupta, M. V., Ahmed, M. M., Bimbao, A., \& Lightfoot, C. (1992). Socio- economic impact and farmers assessment of Nile tilapia (Oreochromis niloticus) culture in Bangladesh. ICLARM Technical Report No. 35, International Center for Living Aquatic Resources Management, Manila, Philippines, 50.

7. Zhang, X., Feng, J., Xu, M., \& Hu, J. (201)1. Modeling traceability information an functionality requirement in export-oriented tilapia chain. $J$ Sci Food Agric, 91: 1316-1325.

8. Qiang, J., Yang, H., Wang, H., Kpundeh, M. D., \& $\mathrm{Xu}$, P. (2013). Interacting effects of water temperature and dietary protein level on hematological parameters in Nile tilapia juveniles, Oreochromis niloticus (L.) and mortality under Streptococcus iniae. infection. Fish Shellfish Immunol, 34:8-16.

9. Shang, Y. C., \& Costa-Pierce, B. A. (1983). Integrated agriculture-aquaculture farming system - some economic aspects. J World Maricult Soc, 14: 523-530.

10. APHA, AWWA and WPCF. (1985). Standard Methods for the Examination of Water and Wastewater (16th ed.). American Public Health Association, American Water Works Association, Water Pollution Control Federation, Washington DC, USA, 1268. Aquaculture, 101(3-4): 213-222.

11. Gomez, K. A., \& Gomez, A. A. (1984). Statistical Procedures for Agricultural Research (2nd ed.).
12. ADCP. (1983). Fish feeds and feeding in developing countries. Aquaculture Development and Co-ordination Programme. ADCP/ REP/ 83/ 18. FAO, 97.

13. Hossain, M. A., Hossain, A. A., \& Sultana, N. (2005). Over-wintering growth of normal and monosex GIFT Tilapia, Oreochromis niloticus in Bangladesh fed on formulated diet. J. Aqua Trop, 20(4): 291-306.

14. DoF. (2019). Matsha Pakkah Shankalan. Directorate of Fisheries, Government of the People's Republic of Bangladesh, Dhaka, Bangladesh. 81.

15. Michael, R. G. (1969). Seasonal trends in physicochemical factors and plankton of a fresh water fish pond and their role in fish culture. Hydrobiologia, 33(1): 144-160.

16. Latif, M. A., Ali, M. M., \& Islam, M. A. (1986). A comparative physico-chemical study of a well managed fishpond and a derelict pond. Bangladesh J. Aquacult, 6-7(1): 71-78.

17. Wahab, M. A., Islam, M. T., Ahmed, Z. F., Hoq, M. S., Haque, M. A., \& Biswas, B.K. 1995. Effect of frequency of fertilization on the pond ecology and growth of fishes. BAU Res. Prog, 9: 410-419.

18. Green, B.W. 1992). Substitution of organic manure for pelleted feed in tilapia production.

19. Hossain, M. S. (2007. Evaluation of rice bran and wheat bran as a supplemental feed compared to a commercial feed for the monoculture of GIFT tilapia (O. niloticus) in ponds. M. S. Thesis, Department of Aquaculture, Bangladesh Agricultural University, Mymensingh.

20. Hossain, M. A., Roy, R., Rahmatullah, S. M., \& Kohinoor, A. H. M. (2004). Effect of stocking density on the growth and survival of GIFT tilapia, (Oreochromis niloticus) fed on formulated diet. $J$ Agric Rural Dev, 2(1):127-133.

21. Boyd, C. E. (1982). Water quality Management for pond fish culure. Elsevier Science Publisher, The Netherlands, 318.

22. Gupta, M. V., Akhteruzzaman, M., Kohinoor, A. H. M., \& Shah, M. S. (1991). Nile tilapia (Oreochromis niloticus) culture under different feeding and fertilization regimes, 500-504. In: Pullin, R. S. V., Lazard, J., Legendre, M., Amon Kothias, J. B., \& Pauly, D. (eds.). The Third International Symposium on Tilapia in Aquaculture. ICLARM Conf. Proc. 41, 575.

23. Green, B. W., Nagdy, E. L., \& Hebicha, H. (2002). Evaluation of Nile tilapia pond management strategies in Egypt. Aquacult. Res, 33(13): 1037-1048. 